UMBARA

Indonesian Journal of Anthropology

Volume 3 (1) Juli 2018 || eISSN 2528-1569 | pISSN 2528-2115 || http://jurnal.unpad.ac.id/umbara

DOI : 10.24198/umbara.v3i1.25507

\title{
Strategi Koping dan Pemberdayaan Disabel Netra pada Lembaga Wyata Guna di Kota Bandung
}

\author{
Tubagus Tamma Randi Fadillah \\ Program Studi Antropologi, FISIP, Universitas Padjadjaran \\ tbtamma@gmail.com
}

\begin{abstract}
This research describes the lives and development program of visually impaired people in Bandung. This research applied the descriptive-qualitative method in particular life history model. The data were collected through observation and interview. The results of this research suggest that visually impaired people, especially caused due to accidents are depressed and helpless. They overcome depression in various ways, one of them by participating in empowerment activity. In this activity, they gain massage skills that later become their mainstays of livelihood.
\end{abstract}

Keywords: Visually impaired people, coping strategy

\begin{abstract}
Abstrak
Penelitian ini menggambarkan kehidupan disabel netra di Kota Bandung dan kegiatan pemberdayaan yang mereka ikuti. Penelitian ini menggunakan metode kualitatif deskriptif dengan model life history. Teknik pengumpulan data dilakukan melalui observasi dan wawancara mendalam dengan disabel netra yang tergabung dalam lembaga Wiyata Guna di Kota Bandung. Hasil penelitian menunjukkan bahwa para disabel netra, terutama mereka yang menjadi disabel netra akibat kecelakaan; mengalami depresi dan tidak berdaya. Para disabel netra mengatasi depresi dengan berbagai cara, salah satunya dengan mengikuti kegiatan pemberdayaan bagi disabel netra. Di dalam kegiatan itu mereka mendapatkan keterampilan memijat yang kemudian menjadi andalan mereka dalam penghidupan.
\end{abstract}

Kata kunci: Disabel netra, strategi koping

\section{Pendahuluan}

Disabel atau disabilitas menurut lembaga kesehatan dunia (World Health Organization) merujuk pada kondisi gangguan atau keterbatasan dalam aktivitas yang dialami oleh individu yang berdampak pada terbatasnya partisipasi mereka dalam kegiatan sehari-hari di masyarakat. Gangguan itu bi- asanya berasal dari fungsi atau struktur tubuh individu. Disabilitas dibagi beberapa jenis, yaitu: disabilitas fisik, disabilitas mental, disabilitas intelektual, disabilitas sensorik, dan disabilitas perkembangan (World Health Organization, 2011). Badan Pusat Statistik mencatat sejumlah 10.000 .000 penyandang 
disabilitas di Indonesia pada 2015. Dari jumlah tersebut, 1.773.290 jiwa atau $17.7 \%$ adalah penyandang disabilitas netra (Badan Pusat Statistik, 2015).

Di masyarakat, para penyandang disabilitas, termasuk disabilitas netra masih belum mendapatkan kesempatan hidup yang sama dengan orang non-disabilitas. Bahkan mereka seringkali mengalami stigma dan diskriminasi. Banyak warga masyarakat yang menganggap disabilitas sebagai 'kutukan' ataupun 'malapetaka' bagi individu dan keluarga yang mengalaminya. Ironisnya, anggapan demikian tak jarang justru muncul dari keluarga dekat. Akibat dari anggapan ini, para penyandang disabilitas seringkali mengalami nasib kurang menyenangkan; misal dikucilkan, dikirim ke panti, atau yang terburuk, dipasung. Jikalau para disabilitas masih tinggal bersama keluarganya pun, hak mereka, seperti warisan, seringkali diambil oleh anggota keluarga lain dengan dalih "para disabilitas tidak akan dapat mengelolanya" (Rappler, 2016). Selain itu, para disabel seringkali ditelantarkan oleh keluarga mereka. Padahal, di dalam Undang-undang nomor 8 tahun 2016 telah disebutkan bahwa keluarga tidak dapat berbuat semena-mena pada penyandang disabilitas, atau menyerahkan anggotanya yang menyandang disabilitas fisik ataupun mental dengan mudahnya ke panti. Keluarga harus merawat para penyandang disabilitas agar mendapatkan rehabilitasi klinis yang layak dengan didampingi tenaga ahli dan terapis. Selain merawat dan merehabilitasi, keluarga juga harus selalu memberi dukungan dan motivasi pada para disabel. Sebab, para disabel, terutama disabel fisik, seringkali merasa depresi ketika menyadari perbedaan kondisi fisik mereka dengan orang lain secara umum. Motivasi dari keluarga akan membuat para disabel bersemangat menjalani kehidupan.

Perhatian pemerintah pada hak-hak penyandang disabilitas saat ini memang belum cukup memadai, terutama bagi disabilitas netra. Program pemerintah bagi disabilitas netra pun masih sangat terbatas. Salah satunya program dari Kementerian Sosial Republik Indonesia berupa pendirian PSBN (Panti Sosial Bina Netra). Program ini bertujuan untuk memberikan keterampilan kepada penyandang disabilitas netra sehingga mereka mampu mandiri dan berperan aktif dalam kehidupan bermasyarakat (Wulandari, 2018).

Di Kota Bandung, PSBN Wyata Guna adalah salah satu PSBN yang berada di bawah Dirjen Pelayanan dan Rehabilitasi Sosial Departemen Sosial Republik Indonesia. PSBN ini memberikan layanan rehabilitasi dan perlindungan sosial bagi disabel netra yang meliputi: bimbingan sosial, bimbingan mental, bimbingan fisik, bimbingan keterampilan, dan bimbingan lanjut agar para disabilitas netra dapat mencapai kesetaraan dan kemandirian, serta mampu berperan aktif dalam kehidupan bermasyarakat. PSBN ini juga mempunyai program khusus yang bertujuan memberdayakan disabilitas netra.

Penelitian ini akan mengulas kehidupan para disabilitas netra di Kota Bandung yang tergabung dalam PSBN Wyata Guna; kegiatan pemberdayaan yang mereka ikuti; serta dampak dari kegiatan itu pada kehidupan para disabilitas netra.

\section{Kajian Pustaka}

\section{Disabel Netra}

Kamus Besar Bahasa Indonesia (KBBI) mendefinisikan tunanetra 'tidak dapat melihat'; atau merujuk pada individu yang tidak memiliki kemampuan untuk melihat. Pertuni (Persatuan Tuna Netra Indonesia) mendefinisikan tunanetra sebagai individu yang tidak memiliki penglihatan sama sekali atau mengalami kebutaan total. Sementara itu, Nakata (2003) mendefinisikan disabel netra sebagai orang yang mempunyai ketajaman penglihatan kurang dari $0,3(60 ; / 200)$ atau mereka yang mempunyai tingkat kelainan fungsi penglihatan yang tinggi. Disabel netra memiliki kesulitan secara signifikan untuk membaca tulisan atau ilustrasi meskipun dengan mempergunakan alat bantu kaca pembesar (Nakata, 2003 dalam Rahardja, 2010). 
Kondisi tunanetra memiliki ciri-ciri 1) ketajaman penglihatan yang kurang dari ketajaman yang dimiliki orang yang dapat melihat secara normal; 2) mengalami kekeruhan pada lensa mata atau terdapat cairan tertentu pada lensa mata; 3) memiliki posisi mata sulit dikendalikan oleh syaraf otak; 4) mengalami kerusakan susunan syaraf otak yang berhubungan dengan penglihatan (Sutjihati dan Somantri, 2006).

Selain ciri-ciri tersebut, Hosni (1995) menyebutkan bahwa seorang tunanetra: 1) hanya mengenal bentuk dan obyek (sedikit sisa penglihatan); 2) hanya dapat menghitung jari dari berbagai jarak; 3) tidak dapat melihat tangan yang digerakkan; 4) hanya dapat membedakan gelap, terang atau persepsi cahaya tetapi masih dapat menunjuk sumber cahaya; dan 5) tidak mempunyai persepsi cahaya (buta total).

Faktor yang dapat menyebabkan kondisi tuna netra dapat berasal dari faktor internal dan faktor eksternal. Faktor internal merujuk pada faktor bawaan individu sejak individu berada dalam kandungan. Faktor kelainan gen, kondisi kesehatan ibu, kekurangan gizi, atau keracunan obat merupakan faktor internal yang dapat menjadi penyebab kondisi tunanetra sejak lahir. Faktor eksternal merujuk faktor yang menyebabkan individu mengalami tunanetra setelah lahir. Faktor itu antara lain kecelakaan, terkena penyakit mata, pengaruh alat bantu medis, terkena virus, kurang gizi pada masa perkembangan, kurang vitamin, sakit panas tinggi, dan keracunan (Sutjihati dan Somantri, 2006).

\section{Pemberdayaan}

Secara konseptual, pemberdayaan atau pemberkuasaan (empowerment) berasal dari kata "power" yang artinya kekuasaan atau keberdayaan. Tujuan pemberdayaan adalah membentuk kemampuan orang atau kelompok rentan dan lemah untuk memiliki kekuatan atau kemampuan dalam hal: 1) memenuhi kebutuhan dasarnya sehingga mereka memiliki kebebasan untuk mengemukakan pendapat, bebas dari kelaparan, bebas dari kebodohan, dan bebas dari kesakitan; 2) menjangkau sumber-sumber produktif yang memungkinkan mereka dapat meningkatkan pendapatannya dan memperoleh barang-barang dan jasa-jasa yang mereka perlukan; dan 3) berpartisipasi dalam proses pembangunan dan keputusan-keputusan yang mempengaruhi mereka (Suharto, 2014; Prijono dan Pranarka, 1996 dalam Theresia, et al., 2014).

Pemberdayaan juga bertujuan membentuk individu dan masyarakat menjadi mandiri. Kemandirian tersebut meliputi kemandirian berpikir, bertindak, dan mengendalikan apa yang mereka lakukan tersebut. Kemandirian dicapai melalui proses belajar secara bertahap (Sulistyani, 2004).

Di dalam proses pemberdayaan, manusia merupakan subyek dari dirinya sendiri. Di dalam proses ini, manusia berupaya agar berdaya, mendorong atau memotivasi diri agar mempunyai kemampuan atau keberdayaan untuk menentukan pilihan hidupnya.

Kegiatan pemberdayaan dilaksanakan secara menyeluruh, mencakup aneka bidang: ekonomi, politik, dan sosial budaya. Pemberdayaan di bidang ekonomi merujuk pada upaya menjadikan individu atau masyarakat memiliki ekonomi yang kuat, besar, mandiri, dan berdaya saing tinggi dalam mekanisme pasar yang besar, di mana terdapat proses penguatan golongan ekonomi lemah. Pemberdayaan di bidang politik merujuk pada upaya menguatkan kemampuan individu atau masyarakat dalam mengambil keputusan yang menyangkut kehidupan mereka sendiri; dan di dalam konteks kehidupan berbangsa dan bernegara. Pemberdayaan masyarakat di bidang sosial budaya merujuk pada upaya menguatkan individu atau masyarakat melalui peningkatan, penguatan, dan penegakan nilai-nilai, gagasan, dan norma-norma, serta mendorong terwujudnya organisasi sosial yang mampu memberi kontrol terhadap perlakuan-perlakuan politik dan ekonomi yang jauh dari moralitas (Moeljarto, 1995). 


\section{Metode}

Penelitian ini menggunakan metode kualitatif dengan pendekatan life history. Melalui metode ini, penulis menggambarkan pengalaman informan disabel netra, cara memotivasi dirinya, dan proses pelatihan serta kondisi paska pelatihan di PSBN Wyata Guna. Informan dalam penelitian ini adalah disabel netra dengan penglihatan rendah dan disabel netra total yang sedang atau pernah mengikuti pelatihan di Wyata Guna. Informan dipilih berdasarkan tujuan penelitian yaitu untuk mengetahui pengalaman kehidupan disabel netra sebelum dan sesudah mengikuti pelatihan di Wyata Guna. Data primer dikumpulkan melalui pengamatan terlibat dan wawancara mendalam. Pengamatan dilakukan pada kehidupan keseharian informan termasuk kegiatan mereka di PSBN Wyata Guna. Data sekunder dikumpulkan melalui studi literatur.

\section{Hasil dan Pembahasan}

\section{Panti Sosial Bina Netra (PSBN) Wyata Guna}

PSBN Wyata Guna adalah sebuah panti sosial bina netra yang berada di Jalan Pajajaran No. 52 RT/RW 06/03 Kelurahan Pasir Kaliki, Kecamatan Cicendo, Kota Bandung. Panti ini merupakan lembaga binaan Kementerian Sosial RI dan merupakan PSBN terbesar di Indonesia. PSBN Wyata Guna berperan dalam memberikan bimbingan, pelayanan, dan rehabilitasi sosial yang bersifat kuratif, rehabilitatif, dan promotif dalam bentuk bimbingan pendidikan dasar, fisik, mental, sosial, dan pelatihan keterampilan. Selain itu, PSBN Wyata Guna juga memberikan resosialisasi bimbingan lanjut bagi para penyandang disabilitas netra agar mampu mandiri dan berperan aktif dalam kehidupan bermasyarakat. Kegiatan re-sosialisasi yang disediakan PSBN Wyata Guna berupa pelatihan kemandirian, praktik belajar kerja, bimbingan pembinaan bantuan, stimulan usaha ekonomi produktif, dan penyaluran tenaga kerja. PSBN Wyata Guna juga melakukan pengkajian dan penyiapan standar pelayanan, pemberian informasi, dan rujukan bagi disabel netra.

Di PSBN Wyata Guna terdapat aneka pro- gram kegiatan bagi disabel netra. Para disabel netra dapat bergabung dalam aneka program kegiatan di PSBN Wyata Guna dengan cara melakukan registrasi dan mengikuti proses seleksi. Sebagai bagian dari proses seleksi, petugas PSBN Wyata Guna melakukan kunjungan rumah disabel netra guna melakukan pengamatan pada kehidupan sehari-hari disabel netra dan diskusi dengan keluarganya untuk memastikan bahwa disabel netra layak mengikuti program. Disabel netra yang mengikuti program kegiatan di Wyata Guna diberi fasilitas tempat tinggal di asrama dan tinggal di tempat tersebut selama kegiatan berlangsung. Lembaga ini juga memiliki program bimbingan lanjutan yang bertujuan memantau disabel netra setelah selesai mengikuti kegiatan pelatihan untuk melihat sejauh mana mereka menerapkan keterampilan yang telah dimiliki. Selain kegiatan di dalam lembaga, PSBN Wyata Guna juga memiliki kegiatan pelayanan di luar panti yang berupa penjangkauan (outreach), family care dan day care.

PSBN Wyata Guna juga menyediakan layanan pendidikan luar biasa bagi disabel netra. Layanan pendidikan yang disediakan oleh PSBN Wyata Guna berupa sekolah luar biasa tingkat dasar hingga tingkat menengah. Pada tingkat SMA, SLB Wyata Guna memiliki dua jurusan, yaitu bahasa dan seni musik. Proses belajar mengajar di sekolah ini menggunakan huruf braile.

\section{Strategi koping Disabel Netra}

Penyandang disabel netra mengalami kesulitan dalam kehidupan sosial mereka, seperti dalam hal interaksi sosial, pendidikan, dan pekerjaan. Para disabel netra mengalami kesulitan dalam mendapatkan hak akan pendidikan. Misal, layanan pendidikan formal biasa seringkali tidak menyediakan fasilitas yang memadai bagi disabel netra. Akibatnya, disabel netra harus bersekolah di sekolah luar biasa. Disabel netra juga mengalami kesulitan dalam mencari pekerjaan karena kebanyakan perusahaan tidak membuka lowongan pekerjaan untuk penyandang disabilitas.

Disabel netra melakukan strategi koping agar 
dapat melanjutkan hidup dengan kondisi disabilitas mereka. Mereka memotivasi diri dengan dukungan keluarga atau bergabung dalam lembaga untuk penyandang disabilitas, serta mengikuti kegiatan pelatihan-pelatihan keterampilan untuk meningkatkan keberdayaan mereka.

Individu yang mengalami disabel netra sejak lahir cenderung "pasrah" dan menerima takdir mereka. Namun, mereka pun mengalami depresi ketika baru mengetahui bahwa ia adalah disabel netra dan berbeda dengan orang non-disabel. Biasanya disabel netra sejak lahir mengetahui bahwa mereka disabel netra setelah diberitahu oleh orang lain. Pada awalnya, mereka berpikir bahwa penglihatan yang mereka miliki normal. Pengalaman tidak menyenangkan, seperti dicibir, membuat mereka tidak senang:

"Saya teh paling kesel kalau temanteman saya ingin bermain sepeda. Saya paling lambat jika main sepeda, karena sepedanya saya tuntun, tidak diboseh (tidak dikayuh). Temanteman saya juga langsung ngomongin saya, susah main sepeda sama yang lolong (tunanetra) mah." - Heny, disabel netra sejak lahir

Para disabel netra yang kehilangan penglihatan sejak lahir kebanyakan mengalami kesulitan dalam bersosialisasi. Mereka sangat bergantung pada dukungan keluarga dalam melakukan interaksi sosial dengan orang di sekeliling mereka.

MacArthur dan MacArthur (1998) mendefinisikan strategi koping sebagai upaya-upaya khusus, baik behavioral maupun psikologis, yang digunakan orang untuk menguasai, mentoleransi, mengurangi, atau meminimalkan dampak kejadian yang menimbulkan stress akibat dari adanya tuntutan internal dan/atau eksternal yang melebihi sumber-sumber yang dimiliki individu. Strategi koping dipengaruhi oleh kepercayaan individu terhadap tindakan yang mereka lakukan.

Disabel netra sejak lahir dan akibat kecelakaan memiliki strategi koping berbeda. Disabel netra sejak lahir biasanya lebih mudah menerima kondisi disabilitas mereka dibandingkan dengan mereka yang kehilangan penglihatan akibat kecelakan. Mereka cenderung merelakan dan menerima keadaannya sehingga tidak melakukan apapun dan hal merupakan perwujudan dari strategi koping mereka.

Penyandang disabilitas netra akibat kecelakaan seringkali mengalami depresi hebat dan memerlukan waktu cukup lama untuk dapat menerima dan menyesuaikan diri dengan kondisinya. Perasaan sedih dan sulit menerima kondisi membuat disabel netra lebih banyak mengurung diri di kamar, melamun, dan menarik diri dari lingkungan pada masa-masa awal mereka kehilangan penglihatan. Ketakutan terhadap ejekan orang lain akibat kekurangan mereka merupakan alasan para disabel netra mengurung diri:

"Pas kapungkur mah saya sering kaluar bumi, ameng ka tetangga atau rerencangan nu diditu. Tapi pas tos kajadian mah abdi seueur ngahuleng di kamar, abdi mending cicing di kamar tipadan kaluar soalna sieun nu lain nyarios kumaha-kumaha atau ngaledek kitu. Abdi setiap wengi terus weh ngadua sareng keheul nyalira kusabab naha tiasa hilap mareuman pompa bahan bakar pas basa eta."

(Waktu dulu, saya sering keluar rumah untuk bermain bersama tetangga atau teman-teman di sana. Tapi ketika sudah kejadian, saya lebih sering melamun di kamar, saya lebih memilih diam di kamar daripada keluar rumah, karena saya takut yang lain berbicara yang aneh-aneh atau mengejek saya. Saya setiap malam terus berdoa dan kesal terhadap diri sendiri karena lupa mematikan pompa bahan bakar saat itu) - Aep, disabel netra akibat kecelakaan.

Mencari pengobatan baik medis ataupun non-medis adalah strategi pertama yang 
dilakukan individu yang mengalami disabel netra akibat kecelakaan. Salah satu tindakan medis yang dilakukan adalah dengan melakukan operasi mata. Pengobatan non-medis biasanya berupa penggunaan jasa dari orang yang dipercaya sebagai “orang pintar". Kebanyakan disabel netra menggabungkan pengobatan medis dan non-medis untuk mendapatkan kesembuhan. Namun, ada pula disabel netra yang sama sekali tidak berupaya mencari pengobatan. Mereka hanya dapat pasrah menerima keadaan, akibat ketiadaan biaya pengobatan.

Aep Saefullah adalah contoh disabel netra yang menggunakan pengobatan medis saja. Ia kehilangan penglihatan karena kecelakaan kerja. Sebelum kehilangan penglihatan, ia bekerja sebagai anak buah kapal. Saat mengalami kecelakaan, ia segera mencari pengobatan medis dengan menggunakan fasilitas asuransi dari perusahaan tempat dia bekerja. Ia tidak menempuh pengobatan non medis karena ia merasa yakin dengan pengobatan medis. Saat pengobatan medis tidak memberikan hasil yang memuaskan, ia memilih pasrah dan tidak menempuh cara pengobatan yang lain.

Yuki Santosa adalah contoh disabel netra yang menggunakan pengobatan non-medis saja. Ia menggunakan pengobatan alternatif berupa hyperbaric ${ }^{l}$ dan akupresur. Ia melakukan karena sudah tidak percaya lagi dengan pengobatan medis.

Doni Setiawan menggunakan pengobatan medis dan non-medis. Pada awalnya, ia menggunakan pengobatan medis. Ia melakukan dua kali operasi di rumah sakit. Operasi pertama dilakukan ketika ada program operasi masal tanpa biaya, sedangkan operasi kedua dilakukan dengan menggunakan ASKES. Saat sudah tak memiliki dana sama sekali, Doni memilih tindakan pengobatan non medis seperti pengobatan alternatif ke "orang pintar".

Brennan et al. (2005) menyebutkan bahwa spiritualitas dan keagamaan adalah salah satu sumber koping yang mempunyai efek tangkal positif terhadap pengalaman hidup negatif seseorang. Individu dengan tingkat spiritualitas atau keagamaan yang tinggi memiliki kemampuan mengatasi depresi dan lebih cepat beradaptasi dengan kondisi disabilitasnya; serta mampu beradaptasi psikososial secara cepat.

Pada penelitian ini, Aep Saefullah, informan yang mengalami disabilitas netra akibat kecelakan, menggunakan aspek spiritual sebagai upaya strategi koping. Aep bergabung dalam sebuah pesantren dan menjadi santri. Kegiatan di pesantren membuatnya termotivasi untuk menerima keadaannya disabilitasnya. Ia mendapatkan dukungan Habib Munjir, tokoh di pesantren tempat ia bernaung, dalam membentuk motivasi itu. Selain dukungan moral dari tokoh di pesantren, ia juga mendapatkan dukungan moral dari kakeknya. Kedua tokoh itu memotivasi Aep dalam hal keikhlasan terhadap qadha (kehendak) dan qodar (keputusan atau takdir) sang pencipta. Selain itu, ia juga belajar menghayati dan menerapkan sifat qonaah (menerima). Motivasi-motivasi itu membuat Aep lebih mendekatkan diri kepada Tuhan dan rajin beribadah. Ia pun perlahan-lahan dapat menerima kenyataan dan menjalankan hidupnya kembali dengan kondisi disabilitas yang dimilikinya; dan ia pun tidak lagi menutup dirinya kepada orang lain.

Disabel netra sejak lahir memiliki strategi koping yang berbeda dengan disabel netra akibat kecelakaan. Heny Rahmawati, seorang disabel netra sejak lahir mendapatkan motivasi melalui ajaran mengenai keagamaan dari kedua orangtuanya dan motivasi ucapan dari ibu dan gurunya. Motivasi itu membuat dirinya lebih ikhlas menerima kondisi disabilitasnya dan hal itu merupakan strategi koping yang ia lakukan:

"Saya sering dikasih motivasi dari Ibu dan guru saya pas sekolah. Saya juga sering dikasih contoh teman-teman kelas saya yang sesama tunanetra. Saya sering berfikir mereka juga bisa tetap belajar dan semangat menjalani

\footnotetext{
${ }^{1}$ Hyperbaric adalah metode pengobatan terapi menggunakan oksigen dengan tekanan tinggi.
} 
hidupnya. Ibu sering memberikan pepatah harus menerima takdir, pasti dibalik kekurangan Heny pasti ada kelebihannya."

Heny mengaku bahwa keluarga memiliki peran yang sangat besar dalam strategi koping yang ia lakukan. Ia beruntung memiliki keluarga yang sangat mendukung sehingga ia dapat menjalani kehidupannya sebagai disabilitas dengan penuh keikhlasan.

\section{Pemberdayaan Disabel Netra}

Di dalam konteks pemberdayaan, manusia adalah subyek dari dirinya sendiri. Proses pemberdayaan menekankan pada proses memberikan kemampuan kepada masyarakat agar berdaya, mendorong atau memotivasi individu agar mempunyai kemampuan atau keberdayaan untuk menentukan pilihan hidupnya. Pemberdayaan biasanya ditujukan pada kelompok atau lapisan masyarakat yang tertinggal (Prijono dan Pranarka, 1996 dalam Theresia et al., 2014). Tujuan yang ingin dicapai dari kegiatan pemberdayaan adalah untuk membentuk individu dan masyarakat menjadi mandiri (Sulistiyani, 2004). Kemandirian tersebut meliputi kemandirian berpikir, bertindak, dan mengendalikan apa yang mereka lakukan tersebut. Kemandirian masyarakat dicapai melalui sebuah proses belajar secara bertahap.

Para disabel netra adalah salah satu kelompok yang tidak berdaya, penelitian ini fokus pada kegiatan pemberdayaan disabel netra di Panti Sosial Bina Netra (PSBN) Wyata Guna di Kota Bandung. Lembaga ini merupakan salah satu lembaga yang menyediakan pelatihan keterampilan bagi disabel netra. Salah satu jenis keterampilan yang diajarkan di lembaga ini adalah memijat. Pada pelatihan ini, para disabel netra diajari teknik-teknik pemijatan. Bahkan mereka diajari teknik-teknik pemijatan untuk tujuan pengobatan penyakit. Selain pelatihan pijat, PSBN Wyata Guna juga memberikan pelatihan berupa keterampilan olah raga, ekonomi kreatif, dan agama. Para peserta wajib tinggal di asrama selama pelatihan berlangsung, kecuali ketika ada keperluan mendadak atau urusan yang penting. Para peserta mendapatkan hari libur pada hari Sabtu dan Minggu.

Pelatihan memijat hanya ditujukan untuk peserta berumur di atas 30 tahun atau peserta yang ingin cepat bekerja dalam bidang pijat. Pelatihan ini berlangsung selama satu tahun. Peserta yang telah lulus pelatihan mendapatkan ijazah dan dengan berbekal ijazah tersebut, lulusan dapat membuka praktik sendiri atau melamar ke panti-panti pijat tuna netra. Salah satu disabel netra, Doni Saputra, menyebutkan alasan ia mengikuti pelatihan:

"Saya bosan dengan pekerjaan memilah ikan di rumah tuh, saya coba aja pelatihan itu pijat. Soalnya di sini masih jarang tukang pijat gitu Kang. Ya semoga ajalah laku nanti di kampung. Saya merasa sangat bersyukur bisa mengikuti pelatihan ini, saya merasa tidak percuma ke Bandung. Setelah saya mengikuti pelatihan ini, saya tahu bagaimana memijat dengan benar. Saya sekarang tau bagian-bagian mana saja dan cara memijatnya dengan benar."

Namun, ada pula disabel netra yang mengikuti pelatihan sekedar untuk menambah keterampilan saja. Salah satu disable netra, Heni, menuturkan alasan ia mengikuti pelatihan di Wyata Guna:

"Saya milih pelatihan ini daripada diem di rumah cuma bantu-bantu Ibu. Mending menambah ilmu yang lainnya sambil nunggu ada lowongan pekerjaan. Sampai saat ini yang saya rasakan ya gitu. Saya sekarang mengerti mijit teh gimana, yang saya kaget sampai ada teori-teorinya gitu. Saya sekarang tau cara mijat, beda banget sama yang saya pikirkan dulu."

Tiga orang disabel netra akibat kecelakaan, Aep Saefullah, Yuki Santosa, dan Doni Setiawan, adalah disabel netra yang mengikuti pelatihan bimbingan memijat praktis dan 
pelatihan keterampilan membuat keset dari kain bekas. Mereka semua menyatakan bahwa pelatihan keterampilan di PSBN Wyata Guna sangat bermanfaat:

"Saya merasa sangat bersyukur bisa mengikuti pelatihan ini, saya merasa tidak percuma ke Bandung. Setelah saya mengikuti pelatihan ini, saya tahu bagaimana memijat dengan benar. Saya sekarang tau bagian-bagian mana saja dan cara memijatnya dengan benar. Saya juga dikasih pelajaran bikin sapu injuk, sapu lidi, keset dari injuk sama bahan bekas. Saya ngerasanya ya sangat dibantu dengan pelatihan yang diberikan." - Doni, disabel netra akibat kecelakaan.

Doni, saat ini telah memiliki keterampilan memijat dan bekerja di rumah bugar. Ia menyatakan bahwa keahlian barunya itu telah mendongkrak perekonomian keluarganya. Bahkan ia telah berhasil membeli telepon genggam dari hasil bekerjanya.

"Saya bersyukur banget Kang kepilih jadi peserta berprestasi. Saya kan di kontrak 1 tahun di rumah bugar, sampai saat ini ya saya jadi tau lapangan pekerjaan saya seperti apa, ya kaya nambah-nambah pengalaman lagi. Selama saya di sana, saya dapat membayar kost-an saya sendiri, makan tidak susah pokoknya bisa menghidupi diri sendiri. Bukannya mau sombong yah kang, saya sering nabung dari sisa uang gaji sama uang tips, Alhamdulillah kemarin-kemarin bisa kebeli hp ini. Saya juga udah punya simpenan uang buat tiket pesawat buat pulang kampung nanti. Saya juga nabung buat nanti modal di Jambi, saya pengennya sih buka panti pijat di rumah soalnya kan daerah rumah saya masih jarang ada panti pijat, kalau udah sukses ya nyewa sendiri enggak akan di rumah." - Doni, disabel netra akibat kecelakaan.

Yuki Santosa, senada dengan dua rekannya, juga telah mendapatkan manfaat dari pelatihan yang ia ikuti di PSBN Wyata Guna. Pelajaran-pelajaran yang ia dapat telah ia terapkan saat bekerja di rumah bugar. Kini, ia sudah bisa memberikan uang jajan yang lebih untuk anak-anaknya dan mencukupi kebutuhan hidup sehari-hari bagi keluarganya. Yuki pun terkadang mempunyai uang lebih untuk diberikan kepada kedua orangtuanya. Yuki menyatakan:

"Awalnya saya teh sebenernya mah males sih gini teh, tapi pas diliat-liat lagi mah, penghasilan saya lumayan Kang selama magang di sini. Saya sangat bersyukur bisa ngasih uang lebih sama bisa lah ngasih buat kebutuhan anak-anak, kadang kalau ada lebih lagi, saya suka ngasih juga ke orangtua. Saya bersyukur sekali Kang bisa kayak gini."

Heny, disabel netra sejak lahir, juga menyatakan mendapat manfaat dari pelatihan itu meskipun ia mengikuti pelatihan hanya sekedar sebagai pengisi waktu luang.

"Saya sekarang mengerti mijit teh
gimana, yang saya kaget sampai ada
teori-teorinya gitu. Saya sekarang
tau cara mijat, beda banget sama
yang saya pikirkan dulu. Tapi ya
sayangnya sih para pelatihnya
suka jarang masuk, apalagi waktu
puasa. Ya saya engga terlalu serius
menyingkapi itu, ya saya emang
niatnya menambah ilmu doang, saya
tetep aja pengennya ngejar cita-cita
saya jadi guru SLB." - Heny, disabel
netra sejak lahir.

\section{Simpulan}

Disabel netra disebabkan oleh faktor internal (gen atau keturunan), dan faktor eksternal (kecelakaan). Perbedaan faktor yang menyebabkan disabilitas, memengaruhi cara penyandang disabilitas netra dalam koping strategi mereka. Disabel netra sejak lahir, cenderung lebih pasrah dalam menerima kondisi disabilitas mereka; sedangkan disabel netra akibat ke- 
celakaan seringkali mengalami depresi hebat terkait disabilitas mereka. Koping strategi yang dilakukan oleh disabel netra adalah mencari pengobatan dan memperkuat aspek keagamaan dalam diri mereka. Penguatan aspek keagamaan di dalam diri disabel netra berperan dalam proses penerimaan diri disabel netra sehingga mereka mampu menjalankan hidup dan tidak menutup diri dari lingkungan. Pengobatan yang dilakukan berupa pengobatan non-medis seperti terapi hyperbaric, akupresur, dan pengobatan dengan menggunakan jasa "orang pintar"; sedangkan pengobatan medis berupa operasi mata. Kondisi disabel netra yang memiliki kekurangan menyebabkan mereka menjadi kelompok yang tidak berdaya. Para disabel netra mengikuti kegiatan pemberdayaan yang dilakukan oleh PSBN Wyata Guna sehingga dapat lebih berdaya. Kegiatan pemberdayaan yang diikuti berupa pelatihan keterampilan massage praktis dan keterampilan membuat sapu serta keset. Keterampilan tersebut dapat digunakan oleh para disabel netra untuk bekerja. Beberapa disabel netra memperoleh pendapatan yang lebih besar setelah mengikuti pelatihan yang diberikan oleh PSBN Wyata Guna, sehingga mereka menjadi lebih berdaya.

\section{Daftar Pustaka}

Badan Pusat Statistik. (2015). Penduduk Indonesia: Hasil Survei Penduduk Antar Sensus 2015. Jakarta: Badan Pusat Statistik.

Brennan, M., Cardinali, G., MacMillan, T., dan Shippy, R. (2005). Religiousness and Spirituality in Vision Impaired Adults.

Hosni, I. (1995). Buku Ajar Orientasi dan Mobilitas. Jakarta: Departemen Pendidikan Nasional, Direktorat Jenderal Pendidikan Tinggi, Direktorat Pembinaan Pendidikan Tenaga Kependidikan dan Ketenagakerjaan Perguruan Tinggi.

MacArthur, J., dan MacArthur, C. (1998). Coping Strategies: Research Network on Socioeconomic Status and Health.

Moeljarto, T. (1995). Politik Pembangunan. Yogyakarta: Tiara Wacana.

Rahardja, D. (2010). Pendidikan Luar Biasa dalam Perspektif Dewasa Ini. Jassi Anakku: Jurnal Asesmen Dan Intervensi Anak Berkebutuhan Khusus, 9(1), 76-88.
Rappler. (2016, Maret 18). RUU Disahkan, Hak Penyandang Disabilitas Dijamin Undang-undang. Retrieved from Rappler. com: https://www.rappler.com/indonesia/126291-dpr-sahkan-uu-penyandang-disabilitas

Suharto, E. (2014). Membangun Masyarakat Memberdayakan Rakyat: Kajian Strategis Pembangunan Kesejahteraan Sosial dan Pekerjaan Sosial. Bandung: PT. Refika Utama.

Sulistiyani, A. T. (2004). Kemitraan dan ModelModel Pemberdayaan. Yogyakarta: Gaya Media.

Sutjihati, T., dan Somantri. (2006). Psikologi Anak Luar Biasa. Bandung: Refika Aditama.

Theresia, A., Andini, K., Nugraha, P. G., dan Mardikanto, T. (2014). Pembangunan Berbasis Masyarakat: Acuan Bagi Praktisi, Akademisi, dan Pemerhati Pengembangan Masyarakat. Bandung: Penerbit Alfabeta.

World Health Organization. (2011). Understanding Disability. Malta: World Health Organization

Wulandari, L. (2018). Panti Sosial Bina Netra di Kota Pontianak. Jurnal Online Mahasiswa S1 Teknik Untan, 6(2), 82-96. 